\title{
Situating Men within Local Terrain: A Sociological Perspective on Consumption Practices
}

Deirdre Duffy

Technological University Dublin, deirdre.duffy@tudublin.ie

Follow this and additional works at: https://arrow.tudublin.ie/buschmarcon

Part of the Family, Life Course, and Society Commons, Leisure Studies Commons, Marketing Commons, Sociology of Culture Commons, and the Sports Studies Commons

\section{Recommended Citation}

Duffy, Dee (2014) 'Situating Men within Local Terrain: A Sociological Perspective on Consumption Practices' competitive paper presented at Consumer Culture Theory Conference (CCT9), Aalto University, Helsinki, Finland, 26-29 June 2014

This Conference Paper is brought to you for free and open access by the School of Marketing at ARROW@TU Dublin. It has been accepted for inclusion in Conference papers by an authorized administrator of ARROW@TU Dublin. For more information, please contact arrow.admin@tudublin.ie, aisling.coyne@tudublin.ie, gerard.connolly@tudublin.ie.

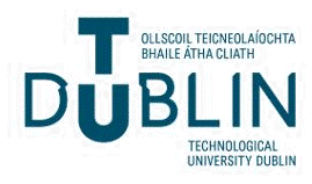




\title{
Situating Men within Local Terrain:
}

\section{A Sociological Perspective on Consumption Practices}

Submission by Dee Duffy, PhD

$6 / 15 / 2014$

\author{
Arthur Ryan Retail Centre \\ Dublin Institute of Technology (DIT) \\ Aungier Street, Dublin 2, Ireland \\ Room \# 2-091 \\ $\mathrm{Ph}:+353-1-402-3214$ \\ Email: dee.duffy@dit.ie
}




\title{
Situating Men within Local Terrain: A Sociological Perspective on Consumption Practices
}

\begin{abstract}
:
The aim of this paper is to explore how young men, operating within influential discursive regimes, construct their identity projects and come to know themselves, through their engagement with consumption and leisure practices. Foucauldian theory is drawn upon to conceptualise men as intertwined within their social environs, the recipients of socio-cultural inscription. By situating the micro-social context of the male consumer in a larger socio-cultural context, this study endeavours to go beyond consumer narratives to incorporate the influence of market and social systems on individuals' identity work. The two discursive practices explored include: hometown community and Gaelic sport. Findings show how identity projects are subject to the workings of power coursing through social networks. Individuals prescribing to a particular identity become subjected to the regulatory mechanisms of their community. However it is shown how subjectification operates differently in the highly structured community of sport compared to the less structured community of a hometown dwelling.

This sociological perspective on men's identity practices highlights the dynamic power forces penetrating social communities, in turn showing the necessity for consumer researchers to anchor the individual consumer experience within their influential environment to gain a more robust understanding of consumer behaviours and consumption practices.
\end{abstract}




\section{Introduction}

Consumer culture theory (CCT) has recently been critiqued for assigning excessive attention to the individual's personal experience in order to gain insights into marketplace activity (Moisander, Valtonen, and Hirsto, 2009), and for placing too much emphasis on the consumer as an agent who can readily draw upon market-based resources to construct his or her own identity (Askegaard and Linnet, 2011). Instead, there is a call for consumer researchers to locate consumer consumption stories within a broader narrative context of established cultural meanings (Thompson, 1997). This paper aims to address these criticisms. It explores the individual's constructions of identity as situated within historically and locally particular cultural practices. This approach allows a better understanding of how consumers negotiate the world around them, keeping in mind the socio-cultural forces that serve to constrain and enable their activity, both in their daily lives and in the marketplace. (Thompson, Pollio, and Locander, 1994) outline numerous cultural influences that impact consumer behaviour, including social settings, cultural ideals and gender roles. This shift away from individualistic conceptualisations of subjectivity, agency and marketplace activity, towards incorporating particular situational and contextual limits and conditions of social action, allows for the consideration of power relations operating throughout social structures, in turn shaping the subjectivity of individuals in different contexts (Moisander et al, 2009: 337). To this end, engaging Foucauldian theory allowed me to conceptualise men as intertwined within their social environs, the recipients of socio-cultural inscription. Through consideration of the body as produced through discourse as well as disciplinary practices, Foucauldian theory facilitates exploration of the effects of power (to include the 
influence of peers, family, community, mass media and social institutions) on the individual. The subject remains discursively and socially conditioned in power relations, yet within this configuration the individual's agency to 'define their own identity, to master their body and desires, and to forge a practice of freedom through techniques of the self' (Best and Kellner, 1991) is upheld.

\section{Research Context}

In recent years the Irish media have reproduced numerous reports and statistics on the rising social and mental health issues affecting young men in Ireland. A prominent voice on this issue, journalist John Waters, has repeatedly suggested that it is Irish society and societal systems that are culpable for young men's 'individual feelings of despair, isolation and meaninglessness' (Waters, 2012). Elsewhere it is reported Irish men are reluctant to communicate personal problems for fear of appearing unmanly (Kiernan, 2009). It was within this climate of rising concern for young Irish men that I recognised the need to explore further how young men construct their identity projects. And furthermore how wider social and cultural forces influence these constructions of identity. Consequently, in order to identify the social constraints and cultural continuities working upon individual men, I situate my respondents within the social and cultural context (Askegaard and Linnet, 2011) of their influential discursive regimes. Following the understanding that power relations are rooted deep in the social nexus (Foucault, 1982), I chose specific practices through which to explore men's identity constructs. Each discursive practice serves to locate the subject in his own community of practices, and then to offer a spectrum of possible comparisons, contrasts and overlaps to illustrate the networks of power that weave through systems of social arrangements. By exploring 
how such discursive regimes order individuals' lives, this study shows how the individual subject is intertwined, and constrained, within these societal power networks. With regard to selecting particular discursive practices to explore, this in the end came down to my own rationale as a researcher, and as an Irish citizen with a consciousness of influential communities within Irish culture. As Askegaard and Linnet point out, ultimately the researcher is presented with an infinite range of contexts that could be explored and so an analytical choice eventually has to be made to 'cordon off a part of the analytical field and present it as a contextual domain' (Askegaard and Linnet, 2011: 396). And so I propose my analytical reasoning for choosing two particular discursive contexts to discuss in this paper: hometown community and national sport.

The first context is that of one's hometown community, or what (Wenger, McDermott, and Snyder, 2002) term a 'community of practices'. Traditionally twentieth-century Ireland was regarded as nurturing caring communities bound together by a high degree of social consensus (Ferriter, 2004). However, this positing of the Irish family as sacrosanct within communities is proposed as a mythical conception, with recent scholarship recording changes in family life being driven by economic desire rather than any social or moral responsibility (Kennedy, 2001). It has been suggested that young men in particular have been affected by the demise of the traditional family unit, and the rapidly changing social structures and values in Ireland (Richardson, 2009). It is proposed that such influences impact upon Irish men's constructions of gender (Ferguson, 1998); (Ferguson and Reynolds, 2001); (Magennis and Mullen, 2011). In this social climate of change, it is suggested that modes of masculinity must also be in flux, in order to adapt to these changes (Magennis and Mullen, 2011). And so, stemming from this ongoing discussion 
of Irish society in transition, the once traditional location of one's hometown community and familial roots was selected as an interesting context wherein to explore cultural influences upon men's constructions of identity.

The second discursive practice selected is one of Ireland's national sports - Gaelic football. This emerged as a logical context in which to consider Irish masculinity. In his essay on sport and the body, (Hargreaves, 1987) explains how emphasis on the sporting body is less about the cultivation of proper values and gait, and more concerned with the regulatory production of identity. Sport in Ireland has long been a centrally important vehicle for the transmission of ideology and identity (Cronin, 1999). From its inception, the Gaelic Athletic Association ${ }^{1}$ (GAA) has strategically aligned Irish masculinity with national identity, with the 'GAA man' epitomising the strong, skilful and moral Irishman (Cronin, 2007). The major influence of this sporting organisation within Irish sporting and cultural life, with clubs spread throughout most parishes in the country, made it an attractive field of analysis for this study.

Through consideration of the individual as situated and interconnected within their immediate, influential discursive regimes and practices, this study adds to the structure versus agency debate that pervades consumer culture literature. By exploring the various workings of power to which the individual is subjected in his daily life practices, this paper intends to challenge conceptualisations of the 'free' consumer or, conversely, the 'dominated' consumer. Instead this work responds to Murray's call for consumer studies to explore further the 'dialectic interplay between agency and structure' (Murray, 2002). By exploring the power relations that weave through the mundane practices of

\footnotetext{
${ }^{1}$ The Gaelic Athletic Association (GAA) is an Irish sports organisation founded in 1884. It remains a community-led, wholly amateur sporting association.
} 
individuals' everyday lives, this study aims to show this interchange at work, and thus how identity work is actually carried out in practice. In particular, rather than avoid the complexities and uncertainties that practice-based approaches to research can unfold, this work will seek to explore ambivalences that exist within contexts (Brownlie and Hewer, 2011).

\section{Research Approach}

This paper draws primarily from data collected following in-depth qualitative interviews. In addition, to gain a better understanding of the discursive regime of Gaelic sport, further data was gathered through participant observation at Gaelic football matches, reviewing online Gaelic sport websites, newspaper articles and blogs, close reading of Gaelic sport advertising material, and researching history books recording the history and social significance of Gaelic Sport in Ireland. A constructionist approach is followed to analyse the interview data with the understanding that a consumer's narrated experience is embedded in a social web of possible interpretation. Rather than seeking to discover a respondents 'essential self' within interview data, this research takes a narrative analysis approach, considering individuals storytelling within the context of circulating discourses and power relations. Taking this approach allows us to consider identity projects as 'enmeshed in - and produced within - webs of social relations' (Lawler, 2008).

Holstein and Gubrium, in their constructionist approach to analysing interview data what they term 'the active interview' - are concerned with how people construct their meaning in interviews. It is said that their interest lies in the assembly of this meaning along with what gets assembled; that is, they analyse what interviewees are saying as well as how they say it (Holstein and Gubrium, 1997). These authors explain further how 
'the active interview' is 'not merely to describe the situated production of talk, but to show how what is being said relates to the experiences and lives being studied' (Holstein and Gubrium, 1997: 127). Adhering to the constructionist approach, this researcher proposes to concentrate on the local or situated character of interview-talk when analysing her data, while also, where appropriate, questioning the cultural resources from which interviewees may draw to do their 'local' work (Silverman, 2006: 145).

Transforming a lived experience into language and constructing a story about it is not a straightforward process, but rather such narrative composition is delivered to its audience in a particular moment in history, and draws upon 'taken-for-granted discourses and values circulating in a particular culture' (Riessman Kohler, 2008). Perhaps symptomatic of contemporary preoccupation with postmodern transient identities, the popularity of adopting narrative analysis practice in social research has expanded as it offers interesting stories of individuals constructing 'who they are and how they want to be known' (Riessman, 2008: 7). Certainly within postmodern marketing thought there has been a shift in recent years from understanding people as meaning-giving subjects to locating meaning in the social practices and literary texts that individuals produce (Moisander et al, 2009: 337).

Narrative analysis focuses attention on sequences of action; that is, the researcher focuses on 'particular actors, in particular social places, at particular social times' (Abbott cited in Riessman, 2008: 11). The interview data does not merely reflect people's subjective experience, but rather is considered 'social texts'; that is, 'complex cultural, social and psychological products, which construct a particular version of those experiences' (Moisander et al, 2009: 337). 
Foucault maintains that we are 'subjected to the production of truth through power' (Foucault, 1980: 93). As such, he is not concerned with explaining how true sentences relate to the world. Instead Foucault concerns himself with 'how power produces discourses of truth through "a complex enabling and limiting of discursive actions," that is, by determining "what may and may not be uttered"' (DeAngelis, 2008: 121). Likewise, Riessman purports that narrative analysis is not about trying to determine whether the interviewee is telling the exact 'truth' of the event or story they tell; what is more interesting is the analyst's interpretive work with the document. In particular, exploring "stories that fail the test and diverge from established "truth" can sometimes be the most interesting, indicating silenced voices and subjugated knowledge' (Riessman, 2008: 186). While there are a number of ways in which one can analyse a narrative text, to include thematic analysis and structural analysis, the method most appropriate to this study is dialogical or performance analysis. Dialogical analysis is interested in how social reality is constructed through interaction, whereby what we take in everyday culture to be 'true' is actually produced in daily exchanges. Of particular interest to this study is the manner in which this analysis 'can uncover the insidious ways structures of inequality and power ... work their way into what appears to be "simply" talk about a life' (Riessman, 2008: 115). The close narrative analysis of even a single case can display 'how larger social structures insinuate their way into individual consciousness and identity, and how these socially constructed "selves" are then performed for (and with) an audience' (Riessman, 2008: 116). This analysis aptly lends itself to the Foucauldian theoretical framework followed in this research study. 
Before presenting the research findings, what follows is a short profile of the two groups and the respondents discussed in this particular paper.

The Townland Lads (hometown community): The Townland Lads are a group of five male respondents aged between 28 and 30 years. All respondents have been friends since secondary-level school and grew up together in a provincial town in the midlands region of Ireland. In the interest of discretion, this town will be assigned the pseudonym 'Mooretown'. The two respondents discussed in this paper are Donal and John:

Donal: at 29 years of age Donal is married, with his wife expecting their first child. He is an electrician by trade, although for the past few years he pursued a career in music. He is a member of a relatively successful Irish music band and so has been the focus of much media attention. Donal admits to being uneasy with the lifestyle etched out for him by his management company and would much rather be at home in Mooretown with the lads than up in Dublin at public events. At the time of this interview he reveals that the band plans on announcing that they will take a break from the music scene. Donal welcomes this sabbatical and plans to drum up local business again as an electrician in the town.

John is a 30-year-old sales representative for a well-known coffee brand in Ireland. He lived in Dublin during his early twenties while at college, and also lived in Australia for a year. He returned home to live in Mooretown in his mid-twenties, and although he often considered moving back to Australia, instead he met a local girl, they built a house on his parents' land in the countryside, and recently they celebrated their marriage in their hometown. As yet they have no children. He reflects that the life he has built for himself is the antithesis of what he envisioned for himself at the age of 21. His ambitions for BMW cars and living a 'yuppie lifestyle' subsided and instead he chooses to 'work to 
live rather than live to work'. He reluctantly admits that he conforms to conventional grooming and styling practices; however, he does offer his 'funny-coloured runners' as a flicker of rebellion against his otherwise conformist style.

The GAA Fellas: This group comprises five interviewees between 22 and 27 years of age, all hailing from North County Dublin. For the purpose of this paper just one respondent is discussed. Peter would be well known to GAA followers as he is in the Dublin squad.

Peter: On the cusp of his 21 st birthday, Peter arrived at the penultimate rung on every aspiring young Gaelic player's ladder - a place on the County Senior Football team. Twenty-three years of age at the time of interview, he has a number of Gaelic achievements under his belt. Peter served his apprenticeship as a plumber before being awarded a scholarship to study at a nearby university. Much of Peter's life to date has been shaped and guided by the GAA, with his daily routine centring on football training, competitions and matches. While he may have had to forfeit nightlife socialising to be fit for a Sunday morning match, he sees this as a small sacrifice to make in comparison to the euphoria of collecting a Leinster title trophy in front of 80,000 GAA supporters in Croke Park - headquarters of the GAA.

\section{Findings: The Townland Lads}

The Townland Lads displayed a distinct consciousness of their selves, and how their selves could be acted out within the confines of their hometown community. There appeared to be unwritten rules of acceptability as to how one behaved and dressed 'down the town' (Donal). In particular, one respondent, Donal, a relatively high-profile music band member, struggled greatly with his 'mediated self'; that is, the persona he was required to adopt for stage life, and his 'home self' - Donal the electrician and lad around town. Within his hometown, he rigorously policed his self to ensure he was not seen to be 
'stepping up above the crowd' (Donal). According to Foucault's concept of 'governmentality', Western society is not being ruled by any sovereign or juridical stronghold per se but instead is subjected to an internal policing of its own social body. Throughout the interview with Donal he articulates this concept poignantly when struggling to find a public mediated image that he could realistically embrace in his own personal domain; that is, his hometown.

Donal strives to establish a cohesive identity for himself between his mediated life and his habitual life. While he expresses a clear understanding as to why the band's record label requires them to project a smart, fashionable image for promotional purposes, his resistance to overstepping 'his' comfort zone is resolute. His gauge of what is fashionably acceptable continuously returns to what 'the town' is prepared to accept. An anonymous entity - what I have called the 'Village Voice' - appears to restrict Donal's creativity to express his self in any 'outlandish' fashion.

Donal: ... I suppose it's a matter of getting comfortable with what you're at, but at the time I wasn't, and ya wouldn't have worn that in a pub, or into town ... and if you did, you, you, you were trying to, you were stepping up above the crowd y'know. You were kind of, do you know what I mean, in the sense that, the Mooretown fashion, or whatever people were wearing, like if I wore something outlandish, I was trying to go in and say ... I, I was thinking this is what people were thinking, 'Here's your man, just because he's the drummer in The Band he thinks he can wear this or that'.

Likewise, John a 30-year-old sales representative alludes to this governing 'Village Voice' as he recalls a rare act of rebellious consumption on his part when away from the panoptic gaze of his hometown of Mooretown on a sun holiday. John laments his late teens as he describes it as a bygone era when he was true to his self. He wore his hair long, wore 'combats and the baggy knitted jumpers and the baggy t-shirts with like 
Nirvana and different bands written on it' and was into his music - he literally wore his passion (music) on his chest. And so he describes his rebellion:

John: Again I suppose the biggest kind of contradiction, I kind of, I was drunk on holidays once and I kind of had a flashback to the person I wanted to be, like, I was on holidays with a friend and we got drunk and we were going on our way back to the airport and I got my eyebrow pierced and I kind of, that was maybe me kind of rebelling.

On returning home, John was met with various locals voicing their opinion of his eyering:

John: but like everybody just laughed at me because I had my nice short back and sides (i.e. conventional haircut) but I had an eyebrow pierced.... And kind of, it just, everybody kind of said, 'Fair enough, yeah, it's not bad but it's just not you, the person we know you as you are, it's just not you.'

The final straw came when John's minor act of individualisation risked him being banned from a family wedding. When asked how long he kept the piercing:

John: Around three weeks 'cos my brother was getting married and again, he'd be a very conformative $[s i c]$ kind of person and he said, 'There's no way you're going to my wedding with an eyebrow ring.'

And so, the 'Village Voice' is indicative of the omnipresent power Foucault conceptualises in his later discussions of power and resistance. It is this ubiquitous power he identifies that can be envisioned metaphorically as being interwoven through societal patterns. There is the temptation at this point to suggest that the Village Voice is a disciplinary technology of the body, being done unto Donal and John, both unsuspecting agents of their own subjection. However to do this would be to dismiss entirely the respondent's individual agency and ability to resist societal forces. Donal is neither trying to shed his self of the shackles of a suffocating society nor trying to liberate his self from 
the pressures of a commercial lifestyle. Rather his search ultimately is in finding a harmonious way to exist, unifying his life themes in an effort to avoid a schizophrenic existence but instead create coherency in his life. Thus in accordance with Foucault's later articulation of power, there is the knowledge that resistance exists in tandem with power, thereby eliminating lofty assertions of oppression or emancipation.

Nonetheless, John makes reference numerous times to 'having to conform', which does depict, in a similar vein to findings by (Shankar, Elliott, and Fitchett, 2009), an aura of his being restricted by his immediate community; in particular he pinpoints his 'career' as a sales representative, and the 'kind of company' he has kept (here John was referring to his hometown friends) as having 'led me down to being clean-cut and kind of looking a certain way'. The agency here is John's reluctant admission that he himself made these lifestyle choices regarding work and friends. However, cloaked within his reluctance lies the decision-processing mechanism powered by a 'legacy of socio-historical influences' (Thompson and Hirschman, 1995), or what Shankar et al (2009) coined as 'narratives of socialisation' whereby John followed prescribed ways of being, almost unconsciously.

So, in a Foucauldian sense, the 'Village Voice' dictating the realms of acceptability for Donal and John can be considered a 'truth', in the sense of that which is made true through discourses. Both young men have constructed a large part of their identity on the basis of being a Mooretown Man and thus, to comfortably align their selves with this geographic association, they need to adhere to the boundaries or 'truths' set by the 'Village Voice' of their hometown. The power being exercised here by the 'Village 
Voice' and its 'truths' is in a sense categorising how a Mooretown Man can behave, which in turn creates a template from which each man can deviate from at his peril.

Here it is seen that while these men 'chose' to attach themselves to specific identities, paradoxically as suggested by Lawler (2008) they have become subject-ed to the rules and norms engendered by a set of knowledges about these identities. This discursive regime, the 'Village Voice', can be seen in a sense to be running these young men's lives, almost without regard of their own role or existence. It is this incapacity to challenge cultural 'truths' or discourses of which Foucault urges individuals to be wary.

\section{Findings: The GAA Fellas}

Peter's stories are littered with anecdotes and examples of the sacrifices he made by pledging commitment to his GAA training regime. He lists various things that he misses out on, such as music festivals and summer holidays (as the GAA football championship runs throughout the summer) or events where he must abstain from a few drinks when everyone around him is indulging, such as his birthday, which falls in summer, his sister's wedding, concerts and weekends in general.

Peter: just all them kind of concerts and things which I would love to go, but now I don't even think about them, it's not as if - I don't even get excited about them or anything like that' cos there's no point' cos I know I'm not going to be able to go to them.

Additionally the level of physical training and dieting that Peter must subject his body to in order to construct his body to a standard worthy of inter-county level performance is intense. He reveals a training programme that officially should span January to October, but actually requires the player train year-round. This is despite the GAA having a rule banning coaches from training their county teams in November and December. Peter says 
that no county observes this rule, and instead they create a 'loophole', devising individual weight training plans for each player and providing them with gym membership courtesy of the GAA. So, technically the rule is being observed in that the players are not training as a team. However, the onus is on the individual player to adhere to this weights regime and have his body in good shape for official training resuming in January.

Peter: What would I be doing? I'd be doing all sorts of weights, like upper-body weights, lower-body weights like trying to build your arms, your chest and your back and then you know kind of squats for your thighs and your hamstrings and just to get your legs, like, as strong and as powerful as possible for the season, like, you know?

Interviewer: And what about diets?

Peter: Diets, yeah, well, in training like that, you'd have, like a high-protein kind of diet, like with maybe some protein shake as well, a supplement like, you know, to repair your muscles after doing weights and yeah, like, we would be told what to eat like you know, well no, we would be given guidelines what to eat like, but like ... at this time of the year [Championship Season], like, you definitely wouldn't be eating anything like that, any kind of bad stuff like you know, you really couldn't.

In conjunction with the normalising gaze of coaches and other GAA officials, a selfsurveillance is in operation. This requires the athlete to take personal responsibility for their actions, and 'in the process of learning the discourse, establish mutual support based on self-reflexivity of what is acceptable and not acceptable' (Johns and Johns, 2000). The sporting practices become normalised in the player's psyche and thus become 'truth'. Peter perfectly captures this integration of the normalising gaze with the internalisation of that made true through discourse:

Interviewer: And even like, when you're having those drinks, do you kind of think, "Are people wondering should I even be drinking?"

Peter: No, I would never care about that you know, I really wouldn't because like, like, fuck them really to be honest with you, like you know, because I'll have a few drinks if I want, they don't know how many I'm having or anything like that so they can't say anything, but I'd feel guilty after drinking more than anything else, you know, I'd be like, 'I can't with a game on, I really can't 'cos it's just - and like, even if it doesn't affect you, it mightn't affect you, you know, 
some people it does, some people it doesn't, but in the week of the game ... I don't think having 10 bottles would affect me in the week before a game 'cos I'd be all right but it would be in your head, you'd be like, “Jesus, maybe I shouldn't have had them" and if you have any doubts like that, like, they can creep in in a game, you know, 'cos you might say, if things aren't going well, you might say, "Oh Jeez, I shouldn't have had them drinks" like you know that kind of way, 'cos then you might think that was the reason why you're not playing well which is probably bullshit but that's what happens in games you know.

Johns and Johns point out how an athlete's process of continual reflection and monitoring leads him to engage in a practice of self-confession (Johns and Johns, 2000: 228). Clearly Peter's narrative 'in his head' and his self-guilt for engaging in 'unacceptable' behaviour reflect a scene akin to a confessional.

Following on from this act of self-care, Peter continues to exhibit such techniques, producing an ethical self. He goes on to describe how he recently went out for dinner in a local pub. On approaching the bar he was confronted by a local whom he vaguely knew who proceeded to ridicule the recent performance of the Dublin team. Peter tells how he would have loved to reciprocate the comment with his own expletives; instead however he dismissed the guy with an idle sigh and a shrug. When probed on this act of restraint, he recites techniques he has learnt from the GAA panel:

Dee: But see, the way you say you can't lose your temper with them, why not? Peter: Well like, it's not, if I lose my temper with them it's just going to make a scene and it's just not - I just kind of nod my head and just kind of get on with it, like, you know? ... I suppose you have to keep discipline but you can't like, you just have to kind of be able to just soak it all in, because like, or just have a kind of force field around you and not listen to any of it, and just listen to whatever's going on within the panel, like, you know. That's the only time I'd really, any time when we're with the panel and we're talking about football or stuff like that, that's the only thing that really matters, about what they'll say, you know, because people are all going to have their opinions. Who really cares about their opinions at the end of the day, like, you know, like they'll ...

Dee: Like, did you just learn to handle it that way so that people ...?

Peter: No, we'd be told to, like we'd have like, we'd have an idea of say a boundary area kind of where we'd have - anything that's inside the boundary area 
is what we talk about in training and then anything outside the boundary area just kind of hits off us, we just don't even take any of it on board even if it is positive.

The GAA panel, including coaches, mentors and management, have provided Peter with tools that he can draw upon to manage his self in an ethical manner, thus avoiding any 'scene' at the bar as may have been his immediate reaction. Certainly technologies of domination are prominent in the above extract, as Peter describes how the 'boundary area' within which he operates (which the GAA devised) will only allow the GAA voice to penetrate. However, as Hargreaves (1987) points out, it is the individual that recognises the necessity of their own discipline who freely submits to governing techniques. Foucault uses the term 'automatic docility' for this dynamic, whereby governing norms become one's own (Cole, Giardina, and Andrews, 2004).

We can see how technologies of the self come into play in the ethical manner in which Peter behaves himself. Foucault maintains ethical work to be "the manner in which one ought to conduct oneself' (Foucault, 1984b). Peter admits that his initial reaction is to wish to retaliate against this heckler; however, his psyche has been infiltrated by ideal GAA player etiquette, and how an inter-county player ought to behave with the public. He has been programmed by the GAA to imagine a 'force field' to protect him from exterior interference, a technique he draws upon in this instance. Such acts of 'selfawareness' or 'self-reflection' Foucault conceptualises as the process of 'self-formation as an ethical subject' (Foucault, 1984: 29). (Markula and Pringle, 2006) state that this process of self-formation requires an individual to initially problematise or critically reflect on the code of conduct and then decipher how best to conduct oneself in response to this code. Peter transformed himself, and his base instincts, to produce himself as an 
ethical subject. However, he is empowered to do so through his influential community, the GAA community.

\section{Further nuances and complexities:}

It has been shown how identity projects take place through the power networks existent within discursive regimes. In particular it was shown how individuals who prescribe to a particular identity become subjected to the regulatory mechanisms operating within their community. Yet this subjectification operates differently depending on the nature of the community explored. The social dynamic of a village community is seldom arranged in any strategic form, but nonetheless hierarchies and social orders emerge. Within this less structured domain technologies of domination operate in a subtle manner upon individuals. And so young men who continue to operate within the subtleties of this prescriptive discursive regime do so unaware of the power relations weaving through their social actions. As long as they continue to exist with this lack of awareness, there is nothing to resist and so new forms of power relationships cannot emerge.

Alternatively we see the social structure of a sport organization as highly structured, with clear lines of authority. Clear objectives, beliefs and expected modes of conduct are communicated to members, who can then choose to join the club or not. In such a community we can see how technologies of the self can be executed. The role of the individual to work on his self as an ethical subject becomes relevant, as he can position his self in relation to a code of moral practice. And so it can be seen that within strategically less structured communities, where technologies of domination govern, individuals subscribe unwittingly to stipulated modes of being. Meanwhile in organised, highly structured communities individuals can be seen to engage in technologies of the self, choosing to subscribe to instructed ways of being. Figure 1 illustrates this structure. 


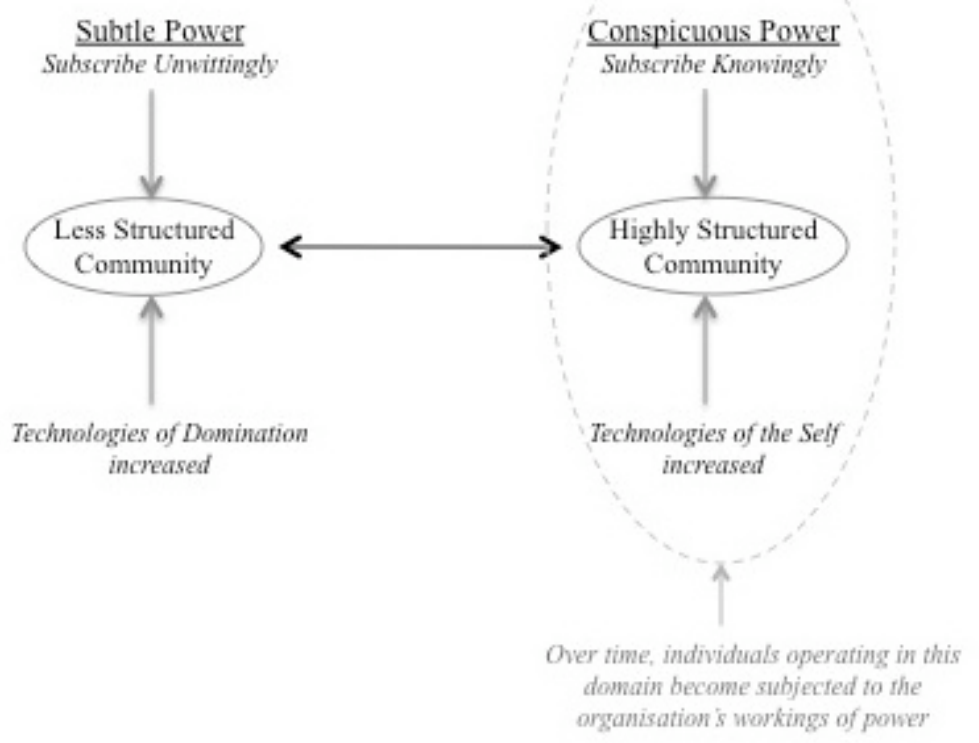

Figure 1: Diagrammatical illustration of power working through highly structured and less structured communities

However, the role individuals play in their implementation or refusal of a particular type of subjectivity should not be confused with any form of social emancipation over those individuals operating within technologies of domination. As these young men subscribe to being a particular type of subject - in this case a Gaelic sportsman - they become subjected to the workings of power that knit through this particular community. When looking at the more highly structured community of the sports organisation, it became evident that while the individual may attempt to transform himself into a desired ethical subject, his work is subject to wider external social influences beyond his own desires and control.

Contribution: To conclude, this paper makes a significant contribution to consumer culture theory. By exploring men's existence within wider social networks, I have shown how these social communities come to influence an individual's life choices and consumption practices. Whether the individual chooses to comply with surrounding 
social norms or seeks alternative modes of being, I show how he is subject to the workings of power flowing through social networks. Future consumer studies need to shift away from understandings of the individual consumer as an autonomous agent to incorporate instead this social dynamic of human interdependency. Moreover, by looking across separate discursive contexts, I have been able to show how individuals become subjected to differing power forces, depending on the dynamic of each discursive regime.

\section{References:}

Askegaard, S and Linnet, J T (2011) Towards an Epistemology of Consumer Culture Theory: Phenomenology and the Context of Context. Marketing Theory, 11(4), 381-404.

Best, S and Kellner, D (1991). Foucault and the Critique of Modernity In Postmodern Theory: Critical Interrogations, Guilford Press, New York.

Brownlie, D and Hewer, P (2011) Articulating Consumers through Practices of Vernacular Creativity. Scandinavian Journal of Management, 27(2), 243-53.

Cole, C L, Giardina, M D and Andrews, D L (2004). Michel Foucault: Studies of Power and Sport In Giulianotti, R (Ed) Sport and Modern Social Theorists, Palgrave Macmillan, London.

Cronin, M (1999) Sport and Nationalism in Ireland: Gaelic Games, Soccer and Irish Identity since 1884, Four Courts Press, Dublin.

Cronin, M (2007). 'Is It for the Glamour?': Masculinity, Nationhood and Amteurism in Contemporary Projections of the Gaelic Athletic Association In Balzano, W, Mulhall, A and Sullivan, M (Eds) Irish Postmodernisms and Popular Culture, Palgrave Macmillan, London.

DeAngelis, P (2008) C.G. Prado, Searle and Foucault on Truth (Cambridge: Cambridge University Press, 2006). Foucault Studies(5), 118-22.

Ferguson, H (1998) Working with Men and Masculinities. Feedback: Journal of the Family Therapy Association of Ireland, 8(1).

Ferguson, H and Reynolds, S (2001) Gender and Identity in the Lives of Irish Men, University College Dublin, Dublin. Available.

Ferriter, D (2004) The Transformation of Ireland 1900 - 2000, Profile Books, London.

Foucault, M (1980) Power/Knowledge: Selected Interviews and Other Writings 19721977, Harvester Wheatsheaf, Hemel Hempstead.

Foucault, M (1982). The Subject and Power In Dreyfus, H a R, P. (Ed) Michel Foucault: Beyond Structuralism and Hermeneutics., Chicago University Press, Chicago.

Foucault, M (1984b) The Use of Pleasure. The History of Sexuality: 2, Penguin, London. Hargreaves, J (1987). Sport, Body and Power Relations In Horne, J, Jery, D and Tomlinson, A (Eds) Sport, Leisure and Social Relations, Routledge \& Kegan Paul, London. 
Holstein, J A and Gubrium, J F (1997). 'Active Interviewing' In Silverman, D (Ed) Qualitative Research: Theory, Method and Practice, Sage, London.

Johns, D P and Johns, J S (2000) Surveillance, Subjectivism and Technologies of Power: An Analysis of the Discursive Practice of High-Performance Sport. International Review for the Sociology of Sport, 35(2), 219-34.

Kennedy, F (2001) Cottage to Creche: Family Change in Ireland, Institute of Public Administration (Ireland), Dublin.

Kiernan, J (2009) Are Irish Young Men in Crisis? Sunday Independent, 27th September 2009.

Lawler, S (2008) Identity: Sociological Perspectives, Polity Press, Cambridge.

Magennis, C and Mullen, R. (2011). Irish Masculinities: Reflections on Literature and Culture. Dublin: Irish Academic Press.

Markula, P and Pringle, R G (2006) Foucault, Sport and Exercise: Power, Knowledge and Transforming the Self, Routledge, London.

Moisander, J, Valtonen, A and Hirsto, H (2009) Personal Interviews in Cultural Consumer Research - Post-Structuralist Challenges. Consumption Markets \& Culture, 12(4), 329-48.

Murray, J B (2002) The Politics of Consumption: A Re-Inquiry on Thompson and Haytko's (1997) "Speaking of Fashion". Journel of Consumer Research, 29(December), 427-40.

Richardson, N. (2009). Getting Men's Health onto a Policy Agenda Charting the Development of a National Men's Health Policy in the Republic of Ireland, 'Nowhere Man' Men's Health Seminar. The Long Gallery, Parliament Buildings,Stormont: Nowhere Man Press.

Riessman Kohler, C (2008) Narrative Methods for the Human Sciences, Sage Publications, Los Angeles.

Shankar, A, Elliott, R and Fitchett, J, A. (2009) Identity, Consumption and Narratives of Socialization. Marketing Theory, 9(1), 75-94.

Silverman, D (2006) Interpreting Qualitative Data, 3rd Edition ed, Sage Publications, London.

Thompson, C (1997) Interpreting Consumers: A Hermeneutical Framework for Deriving Markeitng Insights from the Texts of Consumers' Consumption Stories. Journal of Marketing Research, 34(4), 438-55.

Thompson, C J and Hirschman, E C (1995) Understanding the Socialized Body: A Poststructuralist Analysis of Consumers' Self-Conceptions, Body Images, and Self-Care Practices. Journal of Consumer Research, 22(September), 139-53.

Thompson, C J, Pollio, H R and Locander, W B (1994) The Spoken and the Unspoken: A Hermeneutic Approach to Understanding the Cultural Viewpoints That Underlie Consumers' Expressed Meanings. Journal of Consumer Research, 21(December), 432-52.

Waters, J (2012) We Need to Understand the Rage in Our Midst. Irish Times, July, 13 2012.

Wenger, E, McDermott, R and Snyder, W (2002) Cultivating Communities of Practice: A Guide to Managing Knowledge, Harvard Business School Press. 